\title{
LESSON STUDY: PENINGKATAN KOMPETENSI PEDAGOGIK MAHASISWA PRAKTIK PENGALAMAN LAPANGAN (PPL) DI SMP KOTA TARAKAN
}

\author{
Arifin \\ Pendidikan Bahasa Inggris \\ Universitas Borneo Tarakan, Kalimantan Utara \\ Email: arifin.ubt@gmail.com \\ Uli Agustina Gultom \\ Pendidikan Bahasa Inggris \\ Universitas Borneo Tarakan, Kalimantan Utara \\ Email: ulie_goeltoem@yahoo.com
}

\begin{abstract}
The study was conducted with the purpose to describe the students' motivation in practicing Lesson Study at Teaching Practice Program (PPL) for increasing their pedagogic competence. There were five teacher trainees who joined in Teaching Practice Program and they were as teacher models in Lesson Study at SMP Negeri 3, 5 and 7 in Tarakan. Research design of this research was describtive qualititave with snowballing technique data analysis started on April to October, 2016. Lesson Study consists of three steps; Plan, Do and See. The result of the research can be revealed that 1) students, as teacher trainees, are able to improve their teachng quality through practicing Lesson Study at SMP by having good lesson plan, teaching preparation, classroom management, teaching instructional material, good interaction between teacher and students, 2) the Lesson Study also has significant role in empowering English language teacher trainees to generate the students' performance at the classroom interaction by sharing idea from all teacher trainees in teaching reflection session.
\end{abstract}

Keywords: Lesson Study, Pedagogic Competence, Teaching Practice Program

\begin{abstract}
ABSTRAK
Artikel ini bertujuan untuk mengambarkan hasil penelitian Lesson Study dalam meningkatan kompetensi pedagogik mahasiswa Bahasa Inggris sebagai guru model dalam program Praktik Pengalaman Lapangan di SMP Kota Tarakan, Kalimantan Utara. Jumlah guru model yang terlibat sebagai guru model sebanyak 5 mahasiswa yang melaksanakan praktik pengajaran di SMP Negeri 3, 7 dan 10. Disain penelitian ini menggunakan penelitian deskriptif kualitatif dengan teknik analisis data menggunakan snowballing technique yang dilaksanakan pada awal penelitian April- September tahun 2016, dimana terdapat 2 Siklus dalam pelaksanaan Lesson Study: Plan, Do dan See. Data temuan diperoleh: 1) Mahasiswa sebagai guru model mengalami peningkatan kompetensi pedagogiknya dalam hal mempersiapkan perangkat dalam Rencana Pelakasnaan Pembelajaran agar siswa dapat terbimbing dengan baik dalam memahami materi yang disampaikan oleh guru model (mahasiswa); perencanaan pembelajaran lebih baik, persiapan strategi belajar baik, manajemen kelas baik, penguasaan materi baik, evaluasi dan memotivasi siswa baik. Hal ini berdampak positif bagi prestasi siswa dalam proses belajar mengajar, 2) Interaksi guru model (mahasiswa)-siswa, dan siswa dengan materi pembelajaran juga positif disebabkan guru model mendapatkan banyak masukan atas segala persiapan dalam merumuskan kompetensi pedagogik di dalam kelas.
\end{abstract}

Kata Kunci: Lesson Study, Kompetensi Pedagogik, Praktik Pengalaman Lapangan 


\section{PENDAHULUAN}

Secara teoretik keberhasilan suatu kurikulum secara utuh memerlukan proses panjang, mulai dari kajian dan kristalisasi berbagai gagasan dan konsep ideal tentang pendidikan, pengembangan desain kurikulum, penyiapan dan penugasan pendidik dan tenaga kependidikan, penyediaan sarana dan prasarana, penyiapan tata kelola pelaksanaan kurikulum, pembelajaran, dan penilaian. Semua memerlukan waktu yang cukup untuk berproses dalam menghasilkan satu kebijakan pendidikan yang bermanfaat bagi pelaku pendidikan.

Perbagai upaya yang dilaksanakan oleh Pemeritah dalam terus memperbaiki kualitas, diantgaranya program pendampingan Kurikulum 2013 oleh guru pada tingkatan SD, SMP, dan SMA bertujuan memberikan penguatan dalam memahami konsep Kurikulum 2013 berikut perubahannya di lapangan. Hal ini dimaksudkan untuk membantu mengatasi berbagai kendala yang muncul pada saat pelaksanaan kurikulum tersebut di sekolah. Hal tersebut mengalami kendala dengan pemahaman guru akan implementasi K13 masih jauh dari harapan dan mengalami kesulitan yang sangat berarti. Selain itu, FKIP selaku Lembaga Pencipta Tenaga Kependidakn (LPTK) diharapkan mampu menciptakan kualitas guru yang jauh lebih baik dari sebelumnya. Salah satu upaya yang dapat dilakukan adalah pemgoptimalan Unit Pelaksana Tugas Praktik Pengalaman Lapangan (UPT-PPL) bagi mahasiswa yang telah menempuh teori pendidikan selama 6 sampai 7 semester. Sesuai dengan pelaksanaan penelitian ini dengan melibat sertakan mahasiswa yang mengikuti program PPL dalam praktik Lesson Study (LS) yang sudah lama pernah dilaksanakan di Negara Jepang dengan hasil yang berksinambungan dan berkelanjutan sebagai upaya menciptkan anak didik (Mahasiswa) dapat terus meningkatkan kapasitas dan kompetensi mereka sebagai calon tenaga pendidik baru yang akan terjung mengantikan para guru saat ini.

Praktik pelaksanaan Lesson Study (LS) bagi pendidikan di Indoensia merupakan hal baru yang belum membudaya dan membumi dikalangan para guru, salah satu sebabnya adalah Guru di Indonesia lebih cendrung gelisah dan resah jika tunjangan dan honor mengajarnya ditunda 1 atau 2 bulan dibanding dengan Metode Pengajaran apa yang terbaik bagi generasi dalam memahami kontek pembelajaran yang benar. Lesson Study (LS) dimana diawali dengan Breifing tata cara pelaksanaan LS, kemudia pelaksanaan Teaching Plan, kemudian dilanjutkan dengan PLAN, DO dan SEE akan memberikan kesempatan mahasiswa untuk dapat menguasai kompetensi pedagogik yang baik dan benar karena salah satu indikatornya adalah observasi terlibat langsung melihat proses pengajaran yang disampaikan oleh guru model. Dengan memahami terlebih dahulu perencanaan materi ajaran yang akan disampaikan, lalu melakukan praktik pengajaran pada skala kecil di kelas dan merefeleksi pembelajaran melalui peer assessment sebagai upaya meningkaykan kapasistas dan kompetensi mahasiswa dalam menguasai dan mencapai tujaun dan outcome pembelajaran suatu mata pembelajaran.

Upaya peningkatan kompetensi pedagogik mahasiswa PPL dalam menguasai strategi yang baik, untuk membantu siswa dalam mencapai prestai pembelajaran yang baik diharapkan, dapat membantu guru pamog dan mahasiswa itu sendiri dalam meningkatkan pemahaman terhadap materi yang disampaikan ke siswa. Artikel ini adalah hasil penelitian ini menerapkan praktik Lesson Study oleh mahasiswa pada mahasiswa pendidikan Bahasa Inggris yang ikut memprogramkan Praktik Pengalaman Lapangan (PPL) di sekolah, sebagai wujud berkesinambungan untuk meningkatkan kompetensi pedagogik mahaiswa dalam melaksanakan proses pembelajaran dan mempraktika teori yang telah didapatkan diperkuliahan. Praktik Pengalaman Mahasiswa sebagai wadah mahasiswa LPTK yang menjadi calon guru harus dapat dioptimalkan pelaksanaannya sebagai usaha untuk mengantisipasi akan kompetensi guru yang melemah saat ini. Permasalahan penelitian ini adalah 1) Bagaimanakah peningkatan kompetensi pedagogik mahasiswa pendidikan Bahasa Inggris pada praktik pengalaman lapangan (PPL) di SMP?, 2) Bagaimanakah motivasi mahasiswa dalam upaya peningkatan kompetensi pedagogik pada praktik pengalaman lapangan di SMP? Dengan tujuan penelitian adalah 1) Mendiskripsikan hasil Lesson Study dalam upaya peningkatan kompetensi pedagogik mahasiswa jurusan pendidikan Bahasa Inggris dalam mengikuti Praktik Pengalaman Lapangan di Sekolah, dan 2) Mendiskripsikan motivasi mahasiswa dalam upaya peningkatan kompetensi pedagogik dengan Lesson Study (LS) pada praktik pengalaman lapangan (PPL) di SMP. 


\section{METODE PENELITIAN}

Jenis penelitian ini adalah deskriptif kualitatif yang bertujuan untuk mendapatkan gambaran dari hasil proses pelaksanaan Lesson Study di Sekolah Menengah Pertama (SMP) di Kota Tarakan. Penelitian kualitatif merupakan penelitian yang digunakan untuk menyelidiki, menemukan, menggambarkan, dan menjelaskan kualitas atau keistimewaan dari pengaruh sosial yang tidak dapat dijelaskan, diukur atau digambarkan melalui pendekatan kuantitaif (Saryono, 2010: 1). Penelitian ini telah dilaksanakan Sekolah Menengah Pertama (SMP) di Kota Tarakan. Sekolah Menengah Pertama (SMP) Negeri 3, 5 dan 10 Kota Tarakan, serta 5 mahasiswa PPL terlibat sebagai Guru Model.

Dalam penelitian ini, penelitia menyusun skema prosedur penelitian untuk dapat lebih memahami tahapan demi tahapan dalam pengumpulan data, reduksi data dan analisis data, serta deskripsi hasil temuan penelitian.

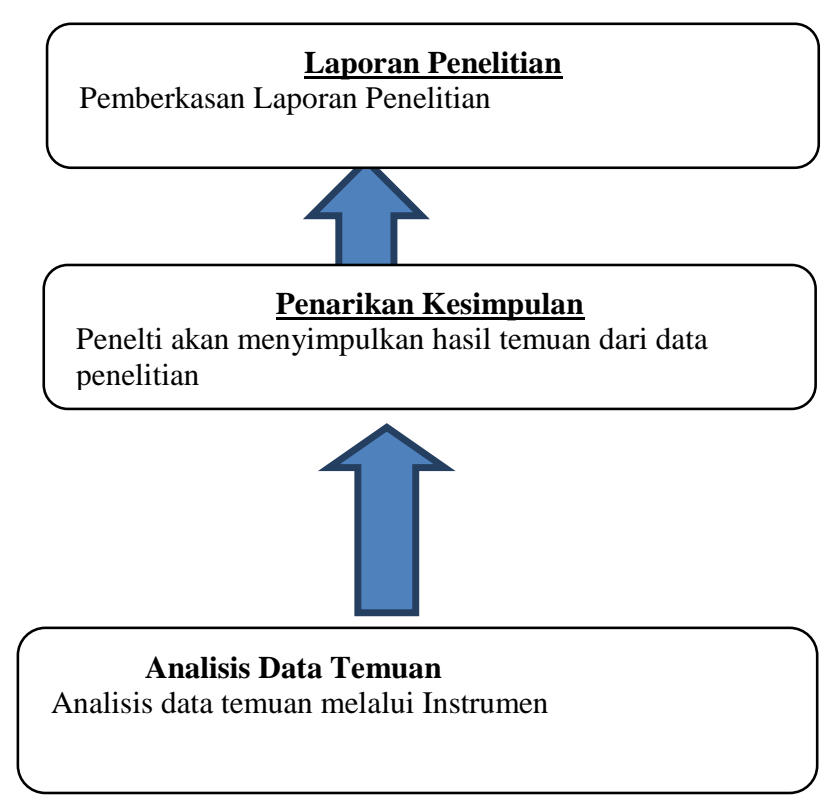

Analisis data dilakukan setelah data yang bersumber dari beberapa instrument terkumpul. Data tesebut akan direduksi lalu dianalisis. Analisis data menggunakan teknik snowballing, data ditemukan sejak mula dari penelitian, proses pelaksanaan LS, wawancara, dokumen yang didapatkan sampai pada penarikan kesimpulan, dimana data tersebut termasuk didalamnya hasil wawancara dipaparan atau diinterpretasikan dalam penjelasan lebih rinci dan lebih. Nasution dalam Sugiono (2008: 245) menyatakan bahwa analisis telah mulai sejak merumuskan dan menjelaskan masalah, sebelum terjun ke lapangan, dan berlangsung terus sampai penulisan hasil penelitian.

\section{HASIL DAN PEMBAHASAN}

\section{Hasil}

Pelaksanaan Siklus Pertama. Pada tahapan pertama Lesson Study, yaitu PLAN. PLAN dilaksanakan secara bersamaan dengan semua 5 
mahasiswa PPL sebagai Guru Model yang terlibat dengan mempresentasikan Rencana Pelaksanaan Pembelajaran (RPP) dan perangkat materi pembelajaran yang diaplikasikan di kelas. Setiap Guru model yang mempresentasikan RPP dan perangkat materi termasuk dimana termasuk didalamnya lembar kerja siswa, soal evaluasi, bahan atau media pembelajaran. Sedangkan guru model lainnya berperan sebagai audiens/ peserta yang memberikan masukkan dan saran terhadapa materi yang disampaikan oleh Guru Model yang bertugas mempresentasikan. PLAN dilaksanakan dengan bergantian dan saling memberikan masukkkan dan saran perbaikan atas RPP; identitas mata pelajaran, SK (KI), KD, indikator pembelajaran, tujuan pembelajaran, materi pembelajaran, kegiatan inti dalam proses pembelajaran, evaluasi yang terdiri dari teknik evaluasi, jenis evaluasi dan contoh evaluasi, media pembelajaran, dan referensi/ sumber pembelajaran dan perangkat materi lain yang disampaikan.

Guru model yang pertama adalah RZ yang mengajar di SMP Negeri 3 Tarakan, pada tahapan Perencanaan LS (PLAN) terdapat banyak revisi yang disampaikan oleh guru model lain sebaimana yang terlihat pada tabel 4.1 before dan after guru model 2 (sdr. Ruzia Sahal) di mana indikator pembelajaran yang dirancang oleh guru model pertama terdapat beberapa revisi pada operasional kata kerja yang terdiri dari dua kata kerja operasional; menyatakan dan menanyakan, sehingga pencapaian indikator pembelajaran tidak fokus pada satu kata kerja operasional. Hal ini juga bertolak belakangan dengan perumusan nilai ketuntasan minimal dimana setiap indikator pembelajaran memiliki nilai pencapaian tersendiri. Berdasarkan revisi, maka setiap indikator pembelajaran hanya terdiri dari satu kata kerja operasional yang dapat memudahkan Guru Model untuk mencapainya melalui penyusunan perangkat evaluasi belajar. Selanjutnya pada tujuan pembelajaran yang terdapat beberapa tujuan, direvisi menjadi dua tujuan pembelajaran tanpa menghilangkan subtansi tujuan pembelajaran sebelumnya. Sementara pada penulisan sumber pembelajaran di RPP direvisi dengan menuliskan dengan jelas nama pengarang, tahun, judul, kota penerbitan dan penerbit. Sedangkan pada bagian evaluasi, guru model sudah mengusulkan rubrik penilaian yang belum jelas penilaiannya sehingga perlu direvisi menjadi rubrik penilaian yang menampilkan penilaian performance siswa di depan kelas.

Tabel 1. RPP before dan after guru model 1

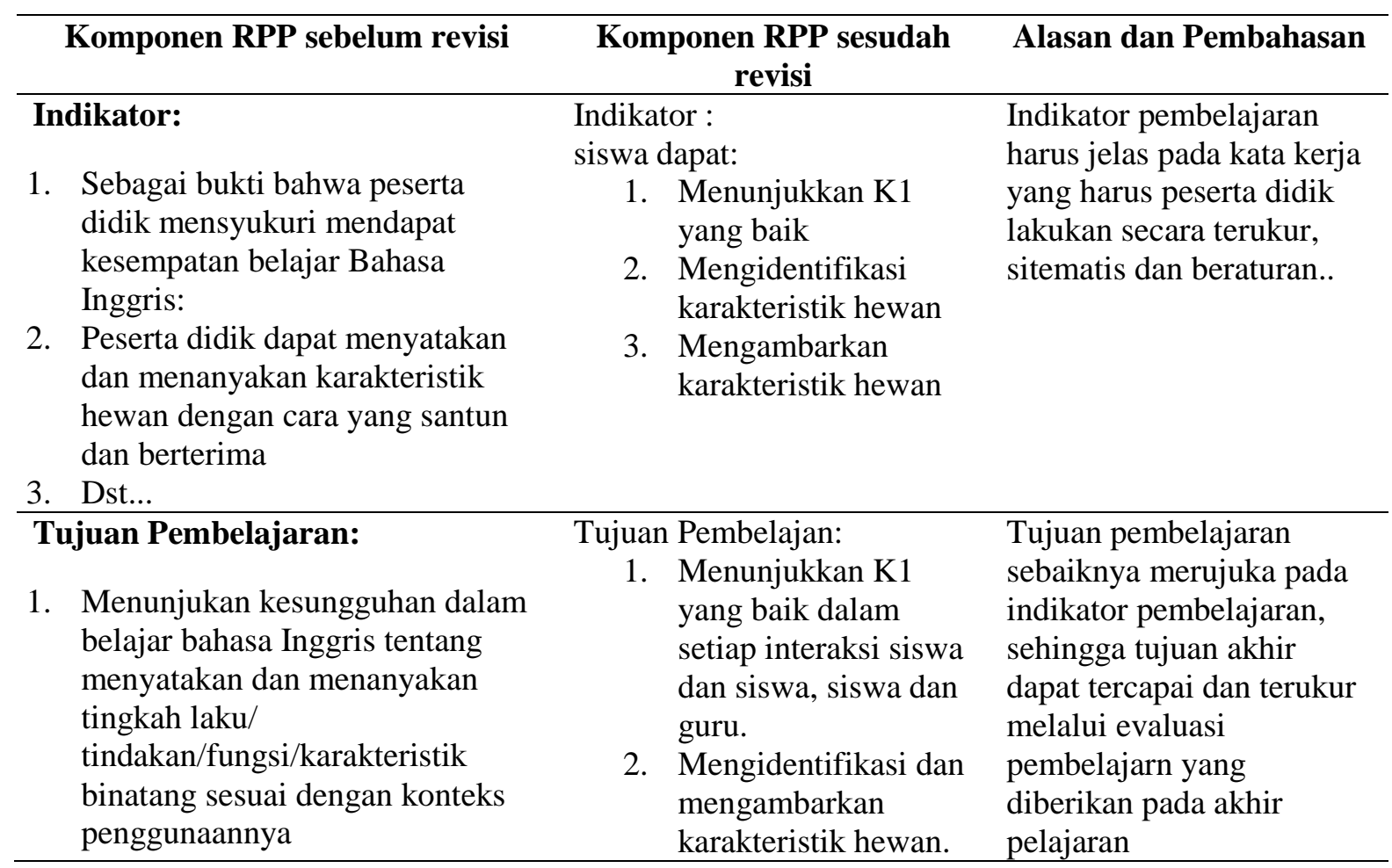


2. Dst...

\begin{tabular}{|c|c|c|}
\hline $\begin{array}{l}\text { Sumber Belajar } \\
\text { 1. Buku Bahasa Inggris “ When } \\
\text { English Rings a Bell” }\end{array}$ & $\begin{array}{l}\text { Kemendibud. 2014. Bahasa } \\
\text { Inggris, When English Rings } \\
\text { a Bell. Jakarta: Pusat } \\
\text { Kurikulum dan Buku, } \\
\text { Kemdikbud. }\end{array}$ & $\begin{array}{l}\text { Sumber belajar harus } \\
\text { tertulis dengan jelas dan } \\
\text { informatif agar observer } \\
\text { atau guru mode lain dapat } \\
\text { menjadikannya sebagai } \\
\text { rujukan pembelajaran bagi } \\
\text { mereka. }\end{array}$ \\
\hline $\begin{array}{l}\text { Penilaiaan: } \\
\text { Rubrik penilian terdiri dari :aspek } \\
\text { adektif, psikootori dan kognitif } \\
\text { serta penilaian yang terdiri dari } \\
\text { penilaian individu, sejawat dll }\end{array}$ & $\begin{array}{l}\text { Guru menekankan pada } \\
\text { aspek kerja kelompok yang } \\
\text { dipresentasikan di depan } \\
\text { kelas sesuai tujuan } \\
\text { pembelajaran, }\end{array}$ & $\begin{array}{l}\text { Pada aspek penilaian } \\
\text { dengan melibatkan siswa } \\
\text { di depan kelas cukup baik }\end{array}$ \\
\hline
\end{tabular}

Pelaksanaan $S E E$ dilaksanakan setelah $D O$ selesai dilakukan di kelas. Pada pelaksanaan SEE, Guru Model 1 memperoleh banyak masukan yang positif pada pelaksanaan LS, karena perbedaan keadaan tersebut, diantaranya pengelolaan kelas yang belum baik, keaktifan siswa yang belum maksimal, beberapa pelaksanaan yang terdapat di DO juga tidak berjalan lancar sesuai dengan harapan pada sesi PLAN. Beberapa pengamat dalam hal ini Guru Model lainnya melihat bahwa pelaksanaan Lesson Study untuk pertama kalinya pada guru model pertama memang menunjukkan beberapa kekurangan, namun mereka melihat secara keseluruhan pada interaksi siswa dan siswa, guru dan siswa cukup berjalan dengan baik. Sementara pengamat lain melihat bahwa interaksi siswa laku-laki/ perempuan dan materi pembelajaran masih terlihat kurang dipahami dengan baik, karena para siswa sebagian masih memperlihatkan ekspresi kebinggungan dalam mengikuti pelajaran Guru Model. Namun, media yang dipergunakan oleh Guru Model cukup variatif karena hal ini dapat membantu siswa untuk memahami materi yang disampaikan.

"untuk guru model kak Ruzia, semua sudah cukup baik, dari pendahuluan, brainstroming sudah berjalan, saya setuju dengan Baruna, karena jika satu kelompok laki-laki semua kecendrungan untuk bermain-main dan tidak belajar kelihatan sangat jelas. Sementara Guru tidak mendatangi pada kelompoj laki-laki tersebut untuk memotivasi. Materinya cukup menarik karena diikuti dengan gambar-gambar. Selain itu, volume suara guru model sebaiknya harus lebih keras guna pemahaman siswa jauh lebih baik"(Novria Asma, observer 2)

Presentasi Guru Model 2. Guru Model 2 adalah sdr. Baruna yang melaksanakan Praktik Pengalaman Belajar di SMP Negeri 10. Dari pelaksanaan PLAN yang disampaikan terdapat beberapa poin yang perlu direvisi sebagaimana terdapat pada Tabel 2 before dan after guru model 2 (sdr. Baruna). Berdasarkan saran dan masukan dari teman-teman Guru model lain dan dosen pendamping, yaitu: pertama, dari jumlah indikator yang direncanakan 3 indikator pembelajaran direvisi menjadi 1 indikator pembelajaran karena ketiga indikator pembelajaran RPP yang belum direvisi menunjukkan kegiatan yang berbeda namun hanya terdapat satu kata kerja operasional yaitu mengidentifikasi, sehingga indikator yang disarankan menjadi $\rightarrow$ siswa dapat mengidentifikasi a) stuktur teks, b) unsur kebahasaan, dan c) fungsi sosial dari teks lisan dan tulis untuk menyatakan dan menanyakan tindakan/kejadian yang dilakukan/terjadi di waktu lampau. Selain itu, pada tujuan pembelajaran juga terjadi perubahan yang menyesuaikan dengan indikator pembelajaran yang telah direvisi sebelumnya. 
Beberapa pengamat memberikan masukan postif perihal pelaksanaan $D O$ di kelas sdr.

Baruna karena interaksi siswa dan siswa terjadi dengan baik, begitu juga interaksi siswa dan guru serta materi pengajaran telah terjadi dengan baik.

Selain itu masukan yang disampaikan dosen pendamping terakait pada aspek evaluasi pembelajaran dengan menggunakan rubrik peniliaan yang perlu direvisi sebelumnya menggunakan beberapa indikator penilaian: Pronounce, Fluency, Accuracy and Intonationi direvisi menjadi Pronounciation and content karena melihat kondisi siswa yang berjumlah banyak dan efektifitas guru model dalam memberikan penilaiaan dengan objektif dan realistis. Pengamat lainnya memberi masukan pada perihal penampilan guru model dalam menyampaikan materi sebaiknya dapat menunjukkan keterlibatan siswa dalam pengajaran dan menjawab pertanyaan, sehingga siswa dapat termotivasi dengan adanya kesempatan yang diberikan oleh guru model.

"Mohon maaf sebelumnya, pronounciation Guru masih ada yang keliru misalnya month dibaca mon yang sebenarnya /man $t \theta /$, because dibaca bikaus yang sebenarnya / bi 'kaz. Penjelasannya sebaiknya 50\% Bahasa dan 50\% Bahasa Indonesia. Ada beberapa siswa, Munandar, Rian yang terlalu sibuk menganggu dan kurang mengikuti pelakaran. Sebaikya dapat menunjuk atau meminta maju ke depan agar dapat membantu siswa lebih fokus. Seharusnya guru dapat menggunakan Gambar yang sesuai agar dapat membuat siswa lebih fokus, selain itu memberi pertayaan, atau menunjuk yang membuat mereka lebih mengikuti pelajaran". (Ruzia, observer 3)

Tabel 2. RPP before dan after guru model 1

\begin{tabular}{|c|c|c|}
\hline $\begin{array}{c}\text { Komponen RPP sebelum } \\
\text { revisi }\end{array}$ & $\begin{array}{c}\text { Komponen RPP sesudah } \\
\text { revisi }\end{array}$ & Alasan dan Pembahasan \\
\hline 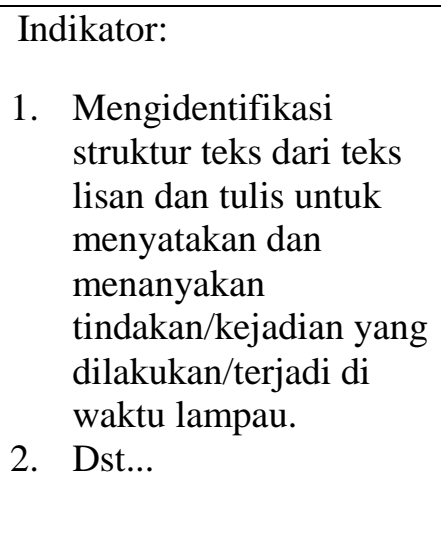 & $\begin{array}{l}\text { Indikator: } \\
\text { siswa dapat: } \\
\text { 1. } \text { Mengidentifikasi a) } \\
\text { stuktur teks, b) unsur } \\
\text { kebahasaan, dan c) } \\
\text { fungsi sosial dari teks } \\
\text { lisan dan tulis untuk } \\
\text { menyatakan dan } \\
\text { menanyakan } \\
\text { tindakan/kejadian yang } \\
\text { dilakukan/terjadi di } \\
\text { waktu lampau }\end{array}$ & $\begin{array}{l}\text { Indikator pembelajaran harus } \\
\text { jelas termaknai dan tidak boeh } \\
\text { berlebihan pada satu kata kerja } \\
\text { operasional yang } \\
\text { dipergunakan, jadi cukup satu } \\
\text { kata kerja operasional yang } \\
\text { dapat diukur dalam } \\
\text { pembelajaran ini, yaitu } \\
\text { mengidentifikasi. }\end{array}$ \\
\hline $\begin{array}{l}\text { Tujuan Pembelajaran: } \\
\text { 1. Know the structural of } \\
\text { Simple Past Tenses. } \\
\text { 2. To explain what things } \\
\text { happened in past. } \\
\text { 3. Perform to share }\end{array}$ & $\begin{array}{l}\text { Tujuan Pembelajan: } \\
\text { Memahami dan mampu } \\
\text { Mengidentifikasi a) stuktur } \\
\text { teks, b) unsur kebahasaan, } \\
\text { dan c) fungsi sosial dari teks } \\
\text { lisan dan tulis untuk } \\
\text { menyatakan tindakan yang } \\
\text { erjadi di waktu lampau }\end{array}$ & $\begin{array}{l}\text { Tujuan pembelajaran tidak } \\
\text { merujuk pada indikator } \\
\text { pembelajaran dan tata bahasa } \\
\text { Gerund dan Infinitive tidak } \\
\text { konsisten }\end{array}$ \\
\hline Kegiatan Pembelajaran & Kegiatan Pembelajaran & $\begin{array}{l}\text { Pelaksanaa Kegiatan awal } \\
\text { dengan mereview } \\
\text { pembelajaran lalu, berfungsi } \\
\text { mengingatkan siswa untuk } \\
\text { senantias belajar di rumah. }\end{array}$ \\
\hline $\begin{array}{l}\text { Kegiatan Inti: } \\
\text { 1. Students recall the }\end{array}$ & Kegiatan Inti & $\begin{array}{l}\text { Pada kegiatan inti sintak } \\
\text { pembelajaran akan }\end{array}$ \\
\hline
\end{tabular}




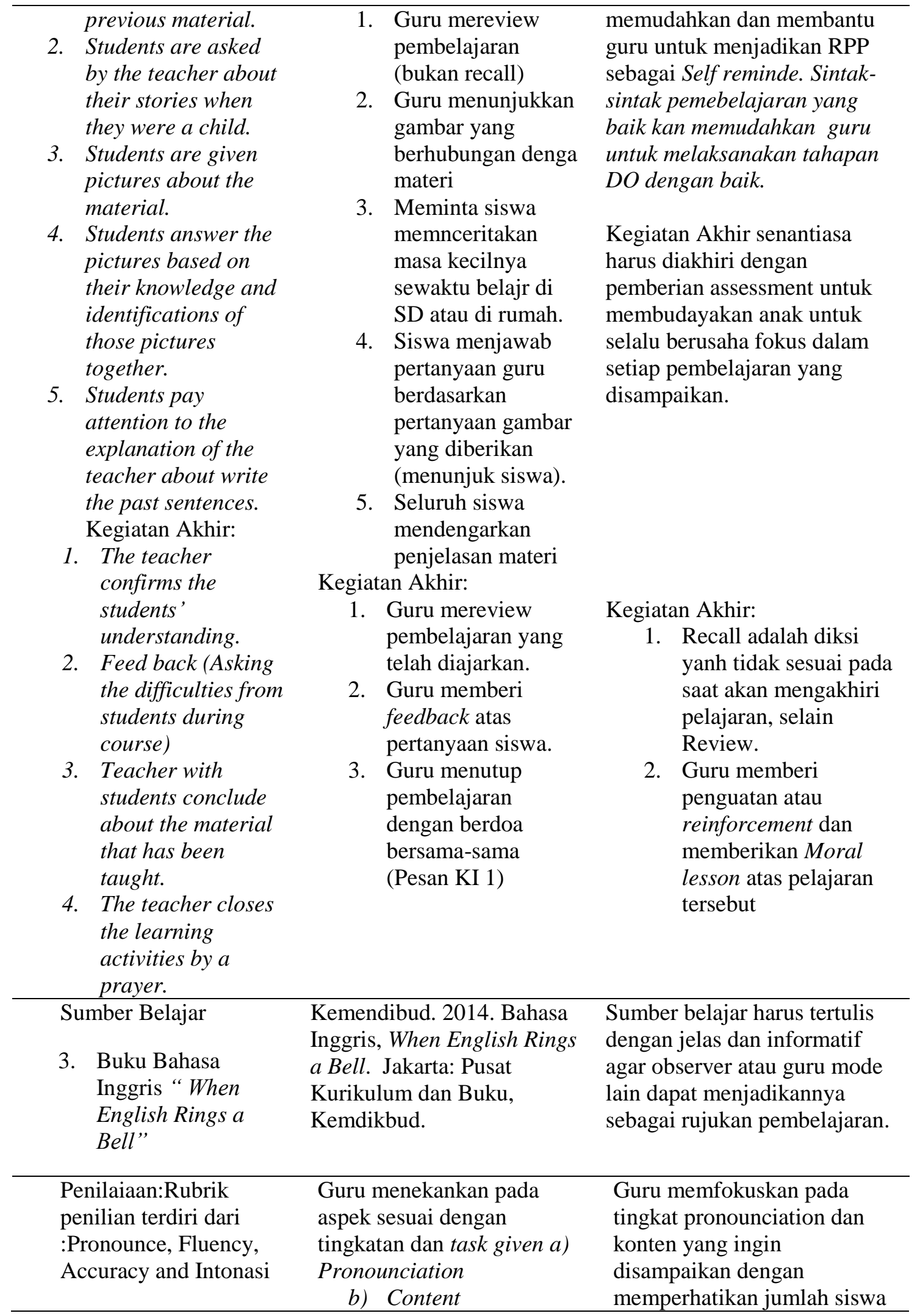

Dari beberapa temuan di tahapan DO untuk Guru Model kedua, terlihat sangat jelas bahwa: 1) kompetensi pedagogik pada aspek pengelolaan kelas atau classroom management masih perlu ditingkatkan, khususnya pada penguasaan kelas yang menitik beratkan pada belajarnya siswa sehingga lebih fokus pada pembelajaran, 2) penguasaan materi pengajaran 
menjadi sangat subtansi karena kesalahan akan menjadikan siswa salah dalam memahami materi ajara yang disampaikan oleh guru, 3) peningkatan pada pengunaan media gambar, sehingga siswa juga dapat terbantu untuk fokus pada materi yang diajarkan, 4) kesalahan konsep; she go, He read yang seharusnya She goes..dan $\mathrm{He}$ reads.. dll dapat memotivasi guru model untuk lebih meningkatkan pedagogik pengajarannnya materi pada siklus ke-2 yang akan datang, 5) metode role play yang disampaikan belum menunjukkan keterlibatan siswa sepenuhnya karena terdapat kesalahan konsep materi yang disampaikan, sebaimana pada poin 4 .

Pelajaran penting yang dapat dipetik adalah pembelajaran yang membuat siswa fokus harus menjadi perhatian pada guru model untuk dapat memberikan pemahaman yang baik atas pelajaran yang disamapaikan, selain itu penguasaan konsep materi ajar oleh guru model merupakan hal yang sangat penting menjadi perhatian guru model karena kesalahan pengajaran akan berakibat kegagalan total dalam mentransformasi pengetahuan dari guru ke siswa. Media juga sangat penting perannya dalam mempercepat pemahaman siswa dan konsentrasi siswa dapat lebih ditingkatkan.

Presentasi Guru Model 3. Pada pelaksanaan PLAN Guru Model 3 (sdr (i) Herlina) juga terdapat beberapa hal yang perlu direvisi, yaitu indikator pembelajaran yang seblumnya berjumlah 4 indikator menjadi 2 indikator pembelajaran hal ini direvisi karena kata kerja operasional yang dapat disederhanakan ke dalam 2 indikator pembelajaran. Demikian juga tujuan pembelajaran yang disampaikan juga mengalami perubahan menyesuaikan dengan indikator pembelajaran yang direvisi. Metode dan materi pembelajaran tidak mengalami perubahan karena cukup baik dan sesuai dengan yang akan diajarkan di dalam kelas,. Pada kegiatan inti sudah terlihat dengan baik dan jelas arah pelaksanaan pembelajaran yang menekankan pada scientific approach; mengamati, bertanya,mencoba,menalar dan mengkomunikasikannya. Sedangkan pada penilaian, terjadi perubahan dari 3 apsek penilaian yang disampaikan menjadi 1 aspek penilaian karena aspek lainnya dapat dilaksanakan pada pertemuan berikutnya.

Tabel 3. RPP before dan after guru model 1 (sdr.(i)

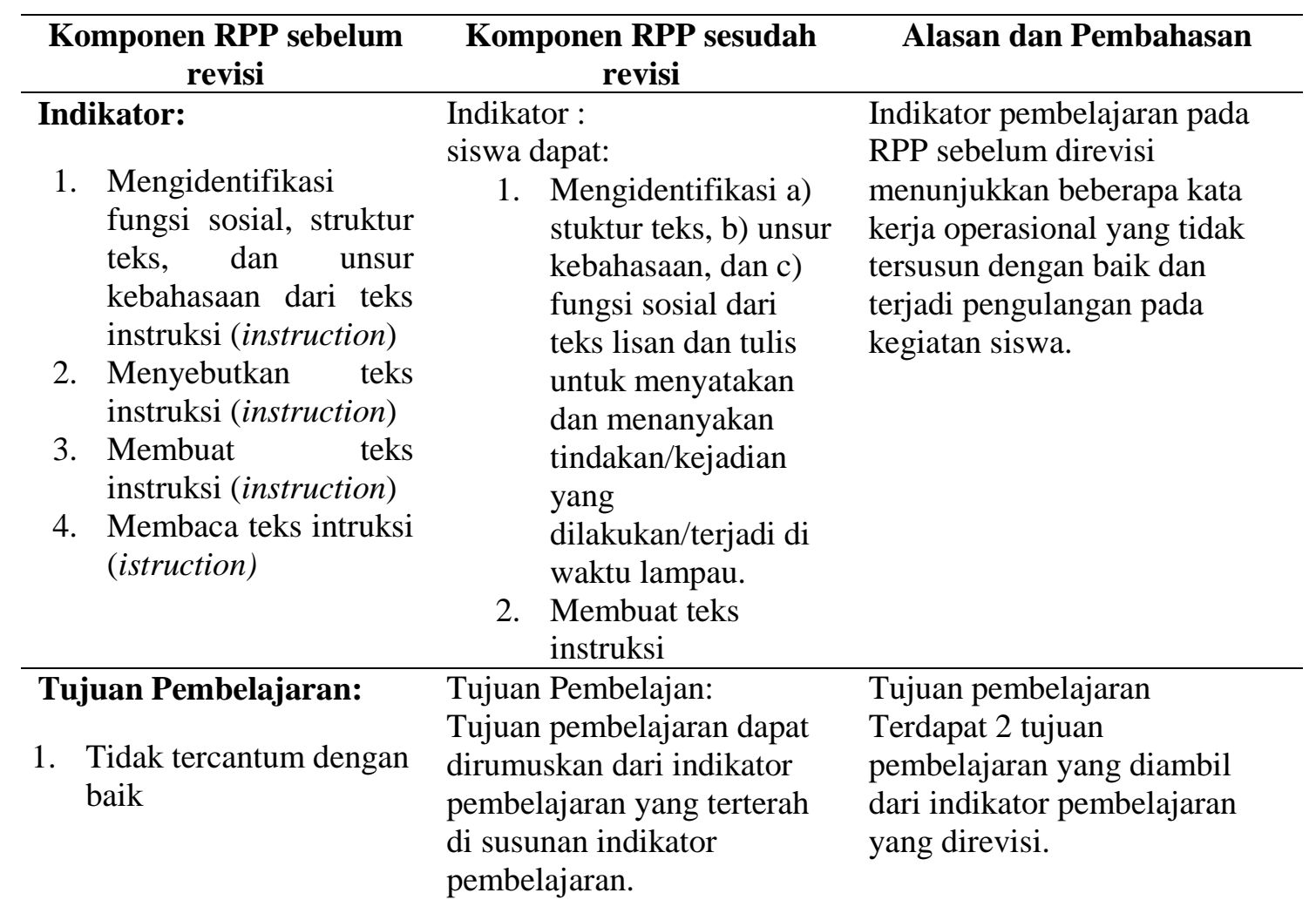




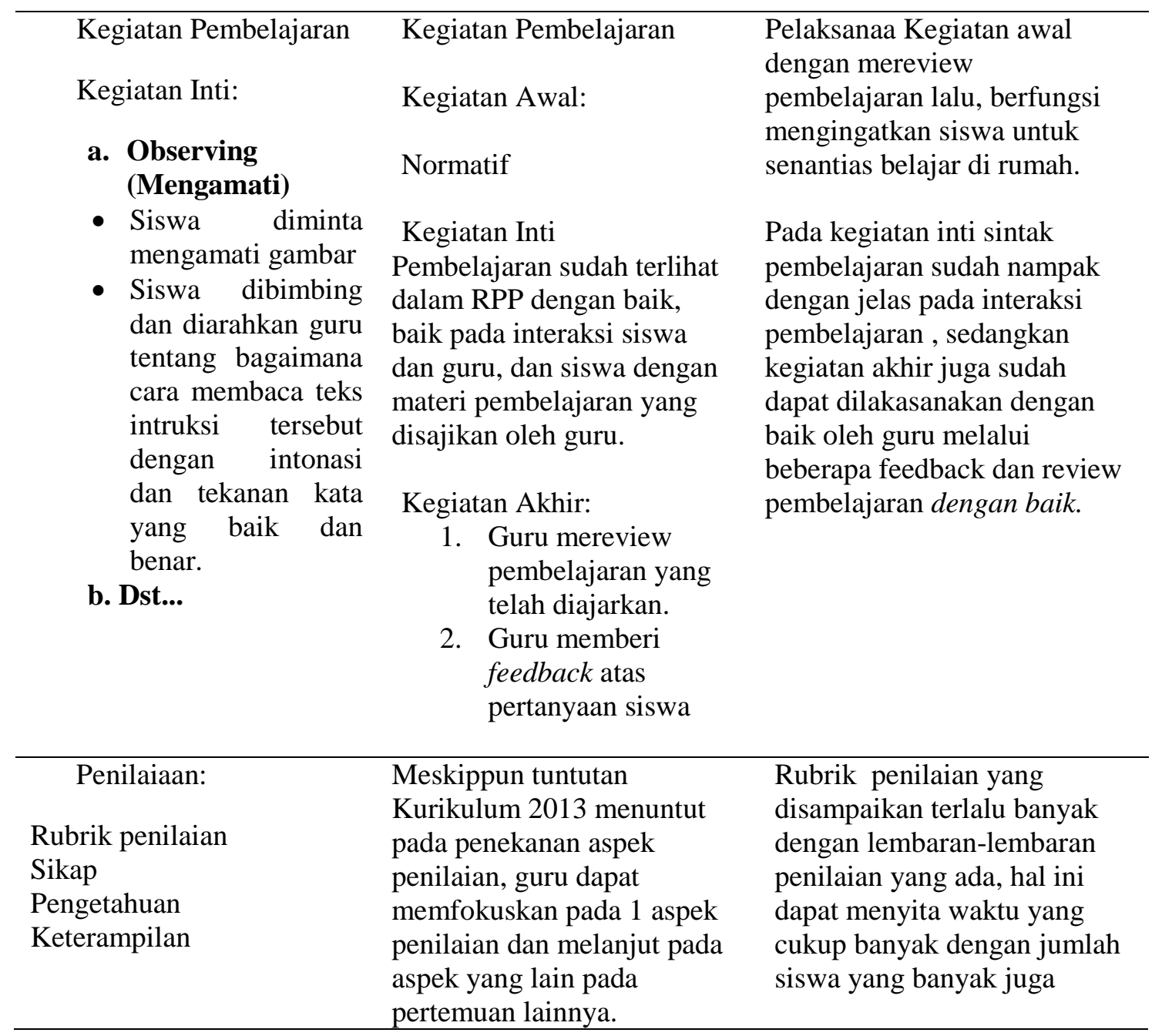

Pelaksanaan SEE dilaksanakan setelah DO selesai dilakukan di kelas. Pada pelaksanaan SEE, guru model banyak mendapat masukan dan saran dari pengamat dan dosen pendamping, diantaranya adalah waktu yang terbatas sedangkan materi pembelajaran belum selesai sepenuhnya sampai tahap evaluasi, dan beberapa siswa belum mengikuti pembelajaran yang ia sampaikan dengan baik. Beberapa pengamat menyampaikan saran bahwa metode yang disampaikan kurang dijelas dipahami oleh siswa di kelas, sehingga konsentrasi siswa tidak fokus pada ibu dan mereka saling menanyakan satu sama lain dalam kelas, hal ini mengakibatkan kebisikan terjadi di dalam kelas selain suasana kelas yang kondisinya cukup panas. Selain itu Agus Hendra menyampaikan bahwa guru sudah cukup baik menjelaskan materi yang dipaparkan di kelas. Semangat mengajar juga nampak dari ibu menjelaskan materi, namun keterlibatan siswa perlu lebih dilibatkan dengan baik. Sementara Novria dan Ruzia menekan partisipasi siswa perlu ditingkatkan dalam proses memahami materi pembelajaran, khususnya siswa yang duduk di posisi belakang, manajemen kelas sudah cukup terlaksana dengan baik.

"Pertama, pelaksnaan pelajaran cukup baik, namun siswa masih belum bisa berkonsentrasi karena suasana ramai. Guru model sudah terlihat bersemangat memberikan pengajaran dan pembelajaran yang baik, akan tetapi fokus siswa terlihat terbagi antara penjelasan dan materi yang mereka pelajari. Secara keseluruhan penjelasan Guru Model cukup baik dalam menjelaskan teks lisan dan tulis, dan struktur teks dan ciri kebahasaan. Menurut pengamatan saya sudah cukup baik pelaksanaan DO oleh guru Model ". (Agus Hendra, Observer 2)

Dari beberapa temuan di tahapan $D O$ untuk Guru Model ketiga, terlihat sangat jelas bahwa:1) kompetensi Guru model cukup baik dalam menjelaskan isi RPP dengan baik, Classroom Management memang perlu terus ditingkatkan oleh guru model, 2) penguasaan materi 
pengajaran menjadi sangat subtansi karena kesalahan dalam pengucapan akan berdampak pada kesalahan dari makna dan arti bahasa, 3) pemanfaatan media pembelajaran sangat subtansi karena dapat memfasilitasi siswa dalam memahami materi, 4) sintak-sintak pembelajaran yang di RPP memang tidak sepenuhnya terjelaskan sesuai dengan rincian di RPP, namun guru model masih dalam koridor pembelajaran yang sesuai dengan RPP, 5) metode pembelajaran sebaiknya dapat disesuaikan dengan materi pembelajaran yang tepat sehigga benar-benar kompetensi tujuan akhir dalam pemebelajaran dapat tercapai dengan baik, dan 6) memotivasi siswa dalam pengajaran merupakan hal penting karena motivasi ini akan terus dibutuhkan oleh siswa dalam proses pembelajaran. Pelajaran penting yang dapat dipetik adalah pembelajaran yang membuat siswa fokus harus menjadi perhatian pada guru model. Model / metode pembelajaran yang disampaikan oleh guru model cukup baik. Kemampuan berbahasa Inggris guru model cukup baik membuat variasi dan contoh pembelajaran yang diajarkan.
Pada pelaksanaan PLAN guru model 4, sdr. Agus Hendra, terdapat beberapa masukan dan saran dari pengamat diantaranya; indikator pembelajaran yang sebelumnya berjumlah 3 indikator menjadi 2 indikator pembelajaran hal ini terjadi karena kata kerja operasional pada indikator dapat disederhanakan dengan baik.

Pada tujuan pembelajaran yang sebelumnya berjumlah 3 menjadi 1 tujuan pembelajaran dengan menggunakan kata kerja operasional yang merangkum semua tujuan pembelajaran menjadi memahami Memahami generic structure dan menyusun karangan descrivtive text dengan baik dan benar. Pada materi dan metode cukup baik dipaparkan di RPP sehingga tidak perlu mengalami perubahan. Pada kegiatan inti terdapat beberapa perubahan pada sintak kata kerja operasional yang lebih tersusun dengan baik, sehingga materi dapat terjelaskan oleh guru model dengan baik. Pada tahap akhir di RPP, penilaian terjadi perubahan dengan memfokus pada penilaian hasil kerja siswa dengan memperhatikan konten, grammar, dan sequence dari main ide pada generic structure

Tabel 4. RPP before dan after guru model 1 (Agus Hendra)

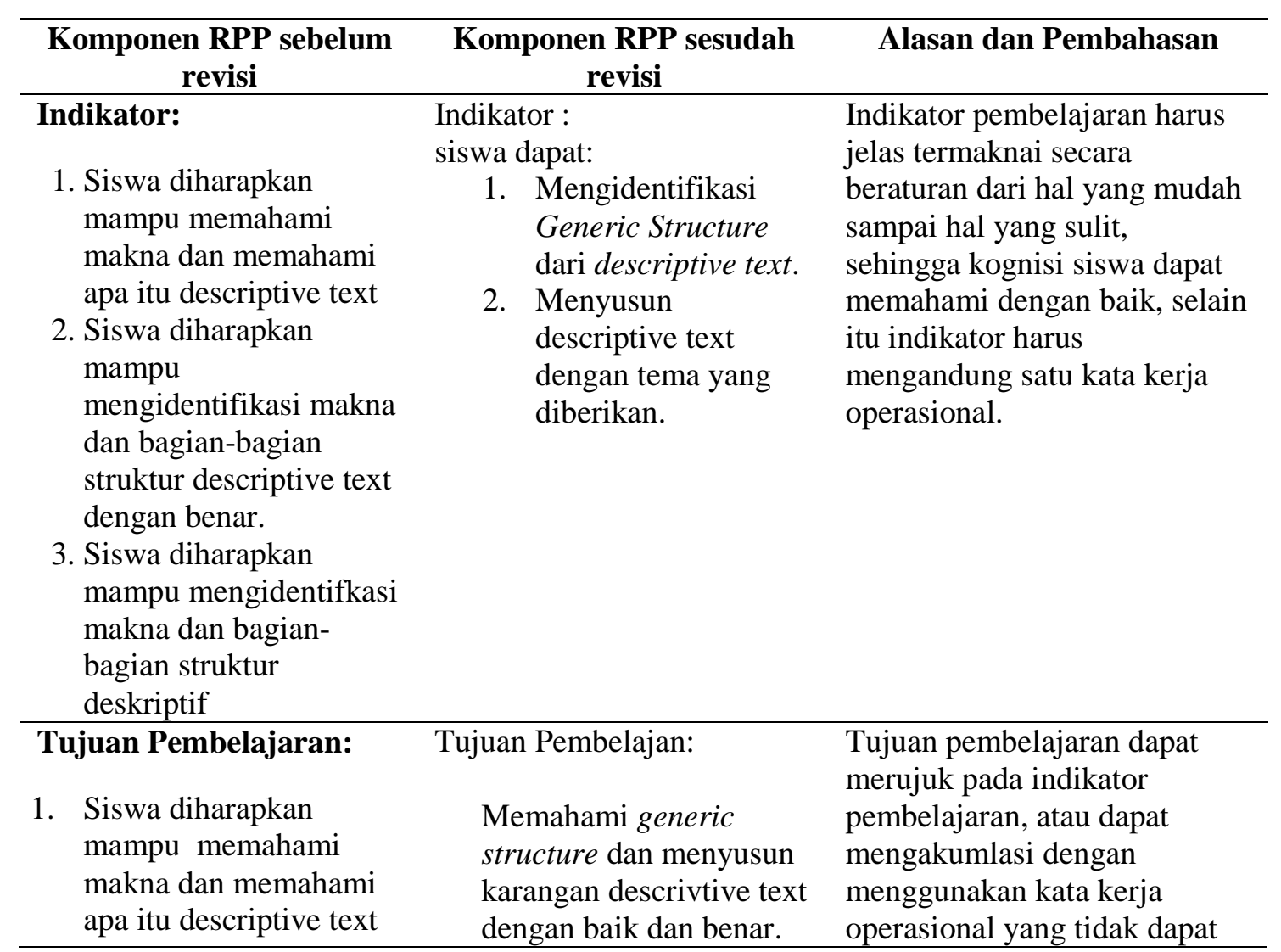


2. Dst...

diukur(memahami,

mengetahui, mengerti dll) atau

dapat diukur (mempraktikan

dll)

Kegiatan Pembelajaran Kegiatan Pembelajaran

Kegiatan Awal:

1. Guru memberi salam kepada siswa

2. Guru menunjuk salah satu siswa untuk memimpin do'a.

3. Guru mengecek kehadiran siswa, dan memastikan siswa telah siap untuk belajar

4. Guru melakukan Tanya jawab dengan siswa terkait materi yang akan diajarkan.

Kegiatan Inti:

1. Guru bertanya kepada siswat tentang Descriptive Text

2. Guru menjelaskan beberapa materi terkait dengan Descriptive Text

3. Guru memberkan contoh Descriptive text kepada siswa, meminta siswa untuk membaca teks tersebut dengan pronunciation yang benar dan mengidentifikasi teks tersebut 4. Dst..

\section{Sumber Belajar}

Buku Bahasa Inggris

kelas VII, Buku Zamrud

SMP Bahasa Inggris kelas VII

Kegiatan Awal:

Cukup baik

Kegiatan Inti

1.Guru memperkenalkan jenis text descriptive dan generic structurenya

2.Siswa diminta memperhatikan dan bertanya jika kurang memahami.

3.Guru menjelaskan pola dan susunan generic structure dengan memberi contoh pada text yang real..

4.Siswa diminta menyusun karangan descriptive text dengan baik dan benar.

Kegiatan Akhir:

Guru mereview

penjelasan dan memeriksa pekerjaan siswa dengan penilaian lagsung atau feedback yang diberikan.
Pelaksanaa Kegiatan awal , Guru sudah dapat menunjukkan K1 dan apersepsi pembelajaran.

Pada kegiatan inti sintak pembelajaran akan memudahkan dan membantu guru untuk menjadikan RPP sebagai pemandu guru dalam melaksanakan proses pembelajaran di dalam kelas.

Kegiatan Akhir senantiasa harus diakhiri dengan pemberian assessment untuk membudayakan anak untuk selalu berusaha fokus dalam setiap pembelajaran yang disampaikan, Guru memberi penguatan atau reinforcement dan memberikan Moral lesson atas pelajaran tersebut serta penilaian langsung atas hasil kerja siswa.
Sumber belajar harus tertulis dengan jelas dan informatif agar observer atau guru mode lain dapat menjadikannya sebagai rujukan pembelajaran.

$\begin{array}{ll}\text { Penilaiaan: } & \text { Guru sebaiknya fokus pada } \\ \text { menggunakan } & \text { penilaian hasil kerja siswa } \\ \text { instrumen tes tertulsi } & \text { dengan memperhatikan } \\ \text { T/F } & \text { konten, grammar, dan } \\ & \text { sequence dari main ide pada } \\ & \text { generic structure }\end{array}$

\section{Dengan adanya penilaian langsung, siswa akan menjadi lebih focus dan bersungguh- sungguh dalam mengerjakan tugas yang diberikan.}

Pelaksanaan SEE dilaksanakan setelah DO selesai dilakukan di kelas. Pada pelaksanaan
SEE, moderator memberikan kesempatan kepada guru model menjelaskan PLAN (briefing 
sebelum open class) dan DO yang telah dilaksanakan. Berikut adalah hasil refleksi dari pelaksanaan tahapan SEE. Pembelajaran yang terkadang tidak sesuai dengan rancangan RPP, hal ini disebabkan karena kondisi guru model yang tidak siap dengan keadaan kelas yang diobservasi dan managemen waktu yang kurang dikuasai oleh guru model. Namun, terlihat dengan baik perbaikan metode mengajar terus ditingkatkan sesuai dengan saran-saran dari pengamat. Herlina memberikan masukan bahwa antara penjelasan atau perintah melakukan atau mengerjakan sesuai dengan LKS tidak sepenuhnya dipahami oleh siswa, sehingga beberapa siswa masih terlihat kebingungan dalam proses penyelesaian.

"Guru model tidak menggunakan brainstorming untuk memancing pemahaman siswa dalam mengikuti penjelasan pelajaran guru model, terlihat tadi guru model langsung pada materi inti, sebaiknya dapat memberi contoh yang terdapat dalam kelas, meja, kursi, papantulis. Perlu penjelasan yang lebih tentang apa saja hal yang dapat dideskripsikan dan ciricirinya., serta pembagian kelompok yang tidak terencana. Interaksi sudah terlihat ketika guru membentuk kelompok"

Dari beberapa temuan di tahapan DO untuk Guru Model kedua, terlihat sangat jelas masukan dari beberapa pengamata untuk perbaikan proses pembelajaran Guru model selanjutnya, diantaranya adalah:

1. Kompetensi pedagogik pada aspek pengelolaan kelas atau classroom management masih perlu ditingkatkan, khususnya pada interaksi dengan siswa yang melibatkan mereka dalam proses pembelajaran, dan memotivasi siswa dalam mengikuti pengajaran.

2. Penguasaan model pembelajaran tidak mendapat porsi yang lebih, karena guru model terjebak pada bagaimana materi tersebut dapat diterima dan diopahami baik oleh siswa.
3. Pengunaan contoh dan cara menerapkannya masih belum maksimal dioptimalkan karena guru model kurang memahami materi disampaikan, namun sarn dari observer memberikan masukan penting bagi perbaikan kompetensi pedagogik guru model.

Pelajaran penting yang dapat dipetik adalah pembelajaran yang membuat siswa fokus harus menjadi perhatian pada guru model untuk dapat memberikan pemahaman yang baik atas pelajaran yang disamapaikan, selain itu contoh deskriptive text yang benar dan cara pembuatan kalimat-kalimat di dalam penting untuk menjadi catatan bagi guru model pada pembelajaran selanjutnya.

Presentasi Guru Model 5. Novria asma adalah guru model yang terakhir yang mendapat masukan dans saran dari pengamat sejak dari pelaksanaan PLAN, DO sampai dengan pelaksanaan SEE. Guru Model 5 yang melaksanakan kegiatan Lesson Study di SMP Negeri 10 Tarakan juga mendapat masukan dalam penyusunan indikator pembelajaran untuk merubahnya dalam indikator pembelajaran yang lebih sistematis atau berurutan(sequence) dengan baik mengenal kemudian mempraktikkannya percakapan dengan menggunakan ekspresi melalui media telepon. Sementara, tujuan pembelajaran dirubah yang sebelumnya berjumlah 3 tujuan menjadi 1 tujuan pembelajaran karena lenih efektif dan mengakomodasi ketiga tujuan sebelumnya.

Kemudian pada pembelajaran inti beberapa pengamat memberikan masukan; 1) melakukan dan mereview pembelajaran melalui pertanyaan singkat, melaksanakan apersepsi pembelajaran yang diajarkan. Pada kegiatan Inti, disarankan untuk menyusun sintak-sintak pembelajaran yang memungkin interaksi antar guru dan siswa, dan siswa dan materi ajar, serta siswa dengan perangkat pembelajaran yang disajikan oleh guru model. Selanjutnya, evaluasi pembelajarn juga disarankan untuk menekankan pada aspek sesuai dengan tingkatan dan task given dengan rubrik penilaian yang menekankan pada performance, pronounciation, grammar, dan content pembicaraan yang dilaksanakan di dalam kelas.

Tabel 5. RPP before dan after guru model 5 (Novria Asma)

\begin{tabular}{llll}
\hline \multicolumn{1}{c}{$\begin{array}{c}\text { Komponen RPP sebelum } \\
\text { revisi }\end{array}$} & \multicolumn{1}{c}{$\begin{array}{c}\text { Komponen RPP sesudah } \\
\text { revisi }\end{array}$} & \multicolumn{1}{c}{ Alasan dan Pembahasan } \\
\hline 1. & $\begin{array}{l}\text { Indikator: } \\
\text { a. Mengidentifikasi suatu }\end{array}$ & $\begin{array}{l}\text { Indikator : } \\
\text { siswa dapat: }\end{array}$ & $\begin{array}{l}\text { Indikator pembelajaran harus } \\
\text { dapat diukur melalui assessmen }\end{array}$ \\
\hline
\end{tabular}




\begin{tabular}{|c|c|c|}
\hline $\begin{array}{l}\text { dialog tentang } \\
\text { percakapan melalui } \\
\text { telephone } \\
\text { b. Mencontohkan ekpresi } \\
\text { yang digunakan dalam } \\
\text { percakapan melalui } \\
\text { telephone. } \\
\text { c. Dst.. }\end{array}$ & $\begin{array}{ll}\text { a. } & \text { Mengenal } \\
\text { kharakteristik dialog } \\
\text { dalam percakapan } \\
\text { melalui telepon. } \\
\text { b. } \\
\text { Mempraktikkan } \\
\text { percakapan dengan } \\
\text { menggunakan ekspresi } \\
\text { melalui media telepon }\end{array}$ & $\begin{array}{l}\text { penilaian yang akan diberikan } \\
\text { dalam pembelajaran di dalam } \\
\text { kelas. }\end{array}$ \\
\hline $\begin{array}{l}\text { 2. Tujuan Pembelajaran: } \\
\text { a. Menjawab pertanyaan } \\
\text { guru atau soal latihan } \\
\text { tentang ekspresi yang } \\
\text { digunakan dalam } \\
\text { percakaan melalui } \\
\text { telephone. }\end{array}$ & \multirow[t]{2}{*}{$\begin{array}{l}\text { Memahami dan mempraktikkan } \\
\text { dialog dalam percakapan } \\
\text { melalui media telepon }\end{array}$} & $\begin{array}{l}\text { Tujuan pembelajaran sebaiknya } \\
\text { merangkum semua indikator- } \\
\text { indikator pembelajaran tanpa } \\
\text { harus menjabarkannya satu per } \\
\text { satu }\end{array}$ \\
\hline b. Dst... & & \\
\hline $\begin{array}{l}\text { Kegiatan Pembelajaran } \\
\text { Kegiatan Awal: }\end{array}$ & 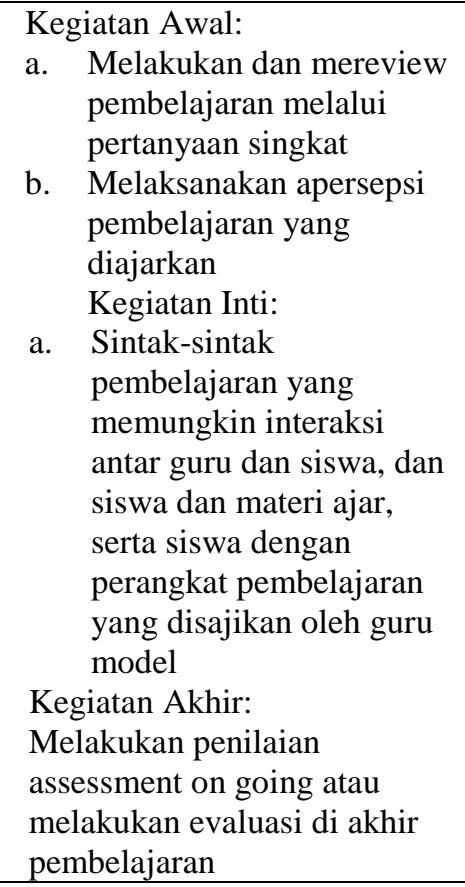 & $\begin{array}{l}\text { Pelaksanaa Kegiatan awal dengan } \\
\text { mereview pembelajaran lalu, } \\
\text { berfungsi mengingatkan siswa } \\
\text { untuk senantias belajar di rumah. } \\
\text { Pada kegiatan inti sintak } \\
\text { pembelajaran akan memudahkan } \\
\text { dan membantu guru untuk } \\
\text { menjadikan RPP sebagai Self } \\
\text { reminder agar Guru Model tetap } \\
\text { pada jalan yang benar dalam } \\
\text { menyampaikan materi } \\
\text { pembelajaran. } \\
\text { Kegiatan Akhir senantiasa harus } \\
\text { diakhiri dengan pemberian } \\
\text { assessment untuk membudayakan } \\
\text { anak untuk selalu berusaha fokus } \\
\text { dalam setiap pembelajaran yang } \\
\text { disampaikan. }\end{array}$ \\
\hline $\begin{array}{l}\text { oud of voice, Intonation, } \\
\text { onunciation, and expression }\end{array}$ & $\begin{array}{l}\text { Guru menekankan pada aspek } \\
\text { sesuai dengan tingkatan dan } \\
\text { task given } \\
\text { 1. Performance } \\
\text { 2. Pronounciation } \\
\text { 3. Grammar } \\
\text { 4. Content }\end{array}$ & $\begin{array}{l}\text { peniliaan speaking performance } \\
\text { sesuai dengan tingkatan dan } \\
\text { fokus pada subtansi percakapan } \\
\text { dengan menggunakan media } \\
\text { telepon. Performance, } \\
\text { Pronounciation, Grammar, dan } \\
\text { Content }\end{array}$ \\
\hline
\end{tabular}

Pelaksanaan Briefing terlebih dahulu untuk mengingatkan kembali kepada semua elemen yang terlibat dalam LS yang mengikuti Open Class di Sekolah Menengah Pertama Negeri 10 pada kelas VIII.

Pelaksanaan SEE dilaksanakan setelah DO selesai dilakukan di kelas. Pada pelaksanaan
SEE, moderator memberikan kesempatan kepada guru model menjelaskan PLAN dan DO yang telah dilaksanakan. Berikut adalah hasil refleksi dari pelaksanaan tahapan SEE. Guru model menyakini bahwa pelaksanaan Lesson Study pada program pengalaman lapangan (PPL) bagi mahasiswa. 
Saran dan masukan terhadapa pembelajaran yang telah dilaksanakan disampaikan oleh para pengamat dengan beberapa poin penting, yaitu praktik pecakapan sebaiknya menggunakan media real, misal percakapan melalui telepon, guru model dapat mengguanakn Handphone siswa atau guru sebagai wujud praktik nyata dalam kelas. Guuru model sudah berupaya maksimal dalam memberi motivasi ke siswa dalam mengikuti proses pembelajaran, karena sudah terwujud interaksi siswa dan siswa, guru dan siswa.

“ Pertama, beberapa siswa nampak tidak begitu mengikuti pelajaran yang disampaikan oleh Guru, hal ini disebabkan oleh karena media (Telepon) tidak disiapkan oleh guru, hal ini dapat memanfaatkan Handphone yang dibawa oleh siswa atau dapat langusng menggunakan Handphone tersebut sebagai contoh real dalam pembelajaran. Kedua, upaya guru mendekati siswa dan memberi semangat cukup baik, interaksi antar guru dan siswa terjadi ketiak guru memberikan motivasi setiap kelompok dengan mendatangi setiap kelompok. Selanjutnya, interaksi siswa dan siswa cukup baik, walaupun beberapa siswa lainnya hanya mengikuti, seperti sdr(a) Riski. (Baruna, Observer 1)

Dari beberapa temuan data di $D O$, terlihat sangat jelas bahwa kompetensi pedagogik guru masih memerlukan penataan yang lebih baik untuk dapat menguasai kelas, siswa dan materi yang diajarkan di kelas. Selain itu, pemanfaatan media belum dapat optimal dipergunakan untuk membantu guru dalam mempersiapakan pelajaran. Metode tanya jawab tidak terlalu dapat dimanfaatkan untuk dapat mengali potensi pemahaman siswa dalam proses pembelajaran berlangsung. Kemampuan pedagogik guru model, khususnya dalam penguasaan materi dan metode untuk dapat memastikan pemahaman siswa atas materi yang disampaikan dapat tercapai dengan baik terlihat jelas. Diskusi kelompok yang dipergunakan belum menunjukkan optimalisasi keterlibatan siswa dalam mengikuti dan memahami materi, hal ini terjadi karena terlihat bahwa ketika guru telah memberikan tugas kelompok, guru hanya menunggu hasil tanpa melihat dan mengobservasi proses terciptanya tugas itu diselesaikan. Sementara, untuk dapat memotivasi siswa dalam pelajaran, guru belum menampilkan materi pelajaran belum menarik siswa, dan masih monoton dengan contoh percakapan dalam telepon dan memberikannya tugas untuk diselesaikan secara berkelompok.

Pada pelajaran penting yang dapat dipetik, hampir semua observer menjadikan pengalaman pertama sebagai observer sangat membantu mereka dalam mempersiapkan open class bagi kelas mereka. Selain itu, kemampuan guru dalam mengelola kelas perlu ekstra kerja keras dan lebih menguasai kompetensi pedagogik dengan variasi yang berbeda sehingga dapat mengoptimalkan siswa dalam interaksi pembelajaran dengan guru dan siswa lainnya.

Pelaksanaan Siklus Kedua ini, temuan dan diskusi hasil penelitian ini difokuskan pada komponen-komponen yang memerlukan perbaikan pada perangkat pembelajaran sebagai strategi guru model dalam pencapaian kompetensi pedagogik guru model yang lebih baik, sehingga dapat berimplikasi positif terhadap prestasi siswa dalam mencapai evaluasi Kriteria Ketuntatasan Minimal (KKM), namun dalam artikel ini tidak menjelaskan pada variabel evaluasi hasil nilai siswa (dijelaskan pada pembahasan lainnya). Pada pelaksanaan Siklus ke-2 diawali dengan pelaksanaan PLAN secara bersamaan yang dengan semua guru model. Para guru model bergantian mempresentasikan Rencana Pelaksanaan Pembelajaran dan semua perangkat pemebelajaran yang catatatan bahwa koreksi dan masukan dalam tahapan PLAN, DO dan SEE pada pelaksanaan Lesson Study pada siklus kedua dan menjadikan RPP dan Perangkat pembelajaran lain sudah lebih baik, serta peningkatan pemahaman pedagogik guru model semakin jauh lebih baik.

Selanjutnya pada sesi PLAN, guru model melalui perangkat pembelajaran yang telah dirancang diberikan saran, masukan dan perbaikan. Pelaksanaan sebagaimana yang telah dilaksanakan pada Siklus Pertama, di mana tahapan-tahapan Lesson Study: Plan, Do, dan See dilaksanakan sesuai kesepakatan dosen pendamping dan guru model (mahasiswa) yang terlibat.

Dari semua presentasi RPP yang disampaikan oleh guru model, semua RPP yang disampaikan sudah cukup baik, hanya saja ada beberapa komponen yang sangat perlu direvisi oleh guru model sebelum pelaksanaan open class pada siklus kedua, sebagai berikut: 
Tabel. 6. Komponen RPP sebelum dan sesudah Revisi Siklus-2

\begin{tabular}{|c|c|c|c|c|}
\hline No. & Guru Model & Komponen RPP sebelum revisi & $\begin{array}{c}\text { Komponen RPP sesudah } \\
\text { revisi }\end{array}$ & $\begin{array}{c}\text { Alasan dan } \\
\text { Pembahasan }\end{array}$ \\
\hline 1 & Ruzia Sahal & $\begin{array}{l}\text { Pembelajaran Inti } \\
\text { - Guru mengecek kesiapan siswa } \\
\text { belajar baik secara fisik maupun } \\
\text { psikologis. } \\
\text { - Guru menanyakan contoh-contoh } \\
\text { narrative text. } \\
\text { - Guru menjelaskan tujuan } \\
\text { pembelajaran atau kompetensi } \\
\text { yang akan dicapai; }\end{array}$ & $\begin{array}{ll}\text { - } & \text { Guru mengecek } \\
\text { - } & \text { kesiapan siswa } \\
\text { - } & \text { Giswa mempersiapkan } \\
& \text { contoh-contoh NT } \\
\text { - } & \text { Siswa secara menjawab } \\
\text { pertanyaan Guru }\end{array}$ & $\begin{array}{l}\text { Sintak-sintak } \\
\text { pembelajaran } \\
\text { sebaiknya harus lebih } \\
\text { detail karena RPP } \\
\text { merupakan guideline } \\
\text { bagi setiap guru dalam } \\
\text { melaksanakan proses } \\
\text { pembelajaran di dalam } \\
\text { kelas (guru penganti } \\
\text { jika sewaktu-waktu } \\
\text { guru tersebut } \\
\text { berhalangan hadir) }\end{array}$ \\
\hline 2 & Baruna & $\begin{array}{l}\text { Penilaian } \\
\begin{array}{ll}\text { a. } & \text { Technique } \\
\text { b. } \quad \text { Instrument } & : \text { Writing test. } \\
\end{array}\end{array}$ & $\begin{array}{l}\text { Evaluasi } \\
\text { Teknik: Tertulis } \\
\text { Instrumen: Essai/ } \\
\text { Menggarang }\end{array}$ & $\begin{array}{l}\text { Teknik peniliaan } \\
\text { tertulis, lisan, non tes, } \\
\text { performance, projek } \\
\text { dll }\end{array}$ \\
\hline 3 & Herlina & $\begin{array}{l}\text { Metode } \quad: \text { Scientific } \\
\text { aproach dengan problem based } \\
\text { learning } \\
\text { Strategi:deduktif. }\end{array}$ & $\begin{array}{l}\text { Metode: Problem based } \\
\text { learning } \\
\text { Strategi: mapping }\end{array}$ & $\begin{array}{l}\text { Scientific approach } \\
\text { sudah otomatis pada } \\
\text { RPP yang } \\
\text { menggunakan K13 }\end{array}$ \\
\hline 4 & Agus Hendra & $\begin{array}{l}\text { Indikator Pembelajaran } \\
\text { 1. Siswa dapat memahami text } \\
\text { procedure } \\
\text { 2. Siswa dapat memahami } \\
\text { makna. } \\
\text { 3. Mengenal } \\
\text { 4. Mengidentifkasi Prosedur } \\
\quad \text { Teks } \\
\text { Tujua Pembelajaran } \\
\text { Untuk memberitahu pembaca } \\
\text { melakukan atau membuat sesuaty } \\
\text { melalui urutan tindakan atau } \\
\text { langhkah }\end{array}$ & $\begin{aligned} & \text { Indikator Pembelajaran } \\
& \text { 1. } \text { Siswa dapat } \\
& \text { mengenal generic } \\
& \text { structure pada } \\
& \text { prosedur teks. } \\
& \text { 2. } \text { Siswa dapat } \\
& \text { menyusun prosedur } \\
& \text { teks } \\
& \text { Tujuan } \\
& \text { Siswa dapat } \\
& \text { memahami } \\
& \text { prosedur teks }\end{aligned}$ & $\begin{array}{l}\text { Kesalahan dalam } \\
\text { penyusunan Indikator } \\
\text { pada RPP kedua ini } \\
\text { adalah indikator tidak } \\
\text { tersusun (sequence) } \\
\text { terhadap materi yang } \\
\text { disampaikan, dan } \\
\text { tujuan sebaiknya dapat } \\
\text { menggunakan kata } \\
\text { kerja operasional } \\
\text { memahami. }\end{array}$ \\
\hline 5 & $\begin{array}{l}\text { Novria } \\
\text { Asma }\end{array}$ & $\begin{array}{l}\text { Eksplorasi } \\
\text { - Guru memperkenalkan teks } \\
\text { Announcement dan memberikan } \\
\text { pertanyaan yang berkaitan dengan } \\
\text { teks tersebut, } \\
\text { - Guru menunjukan contoh } \\
\text { Announcement dan menyampaikan } \\
\text { maksud dari tersebut } \\
\text { - Dst... }\end{array}$ & $\begin{array}{l}\text { - Guru memperkenalkan ciri } \\
\text { announcement } \\
\text { - Siswa diminta } \\
\text { memperhatikan ciri } \\
\text { announcement } \\
\text { - Guru menunjukkan contoh } \\
\text { jenis announcement } \\
\text { - Dst. }\end{array}$ & $\begin{array}{l}\text { Sintak-sintak } \\
\text { pembelajaran } \\
\text { sebaiknya harus lebih } \\
\text { detail pada penjeasan } \\
\text { konteks materi dan } \\
\text { expektsi guru model } \\
\text { terhadapa siswa. }\end{array}$ \\
\hline
\end{tabular}

\section{Pelaksanaan DO}

Pelaksanaan DO telah dilaksanakan pada setiap Guru model di mana mereka melaksanakan Praktik Pengalaman Lanpangan; SMP Negeri 3. 7 dan 10. Setiap guru model melakasanaan DO sesuai dengan RPP dan
Perangkat pembelajaran yang telah disepakati. Guru model lain mengobservasi pelaksanaan DO guru model dari guru model pertama sampai guru model ke-5 secara bergantian dengan melengkapi instrumen observasi yang telah disediakan. Semua data temuan akan dibahas pada pelaksanaan tahapan SEE (Refleksi) agar 
guru modal memahami kelebihan dan kekurangan pada setiap siswa dan guru Model itu sendiri dan guru pamong. Para pengamat mengamati aspek pedagogik guru model, baik pada strategi pembelajaran yang dilakukan, classroom management, evaluasi, dll

\section{Pelaksanaan $S E E$.}

Pada pelaksanaan SEE di siklus kedua ini memfokuskan pada pembahasana hasil evaluasi guru model yang melaksanakan Lesson Study, dimaksudkan agar pemahaman pada kompetensi pedagogik mahasiswa dapat menjadi lebih baik dan meningkat dari sebelum melaksanakan Lesson Study di Sekolah Menengah Pertama (SMP) di Kota Tarakan. Dari pelaksanaan tahapan SEE dapat dinyatakan dalam beberapa poin penting terhadap meingkatkan pemahaman pedagogik mahasiswa PPL dalam melaksanakan Lesson Study di Sekolah, diantaranya 1)

Pelaksanaan DO pada guru model menunjukkan penguasaan kelas yang jauh lebih baik dari LS pada siklus pertama, terlihat interaksi guru dan siswa berjalan dengan baik. (Observer 1)

Walaupun masih terlihat masih kurang, namun interaksi siswa dan siswa, guru dan siswa sudah terlihat dengan baik pada pelaksanaan Lesson Study pada tahapan ini (Observer 2)

Implementasi teori belajar dan strategis pembelajaran nampak dengan guru model teratur dan berurutan dalam mengajarkan materi sesuai dengan tahapan RPP sesuai dengan sesi PLAN sebelumnya. (observer 4)

Sejalan dengan temuan hasil penelitian, berdasarkan UU tahun 2014, pada pasal 10, ayat 1 menjelaskan bahwa yang dimaksud dengan kompeten si pedagogik adalah kemampuan mengelola pembelajaran peserta didik. Kompetensi pedagogik mahasiwa sebagai guru model dalam pelaksanaan Praktik Pengalaman Pengalaman (PPL) di SMP Kota Tarakan memiliki peran subtansi sebagai upaya yanag berkelanjutan dalam menghasilkan calon guru masa depan yang jauh lebih baik dan sesuai dengan tuntutan, guru yang memiliki kompetensi pedagogik yang baik.

Berikut adalah hasil wawancara dari pelaksanaan Lesson Study untuk peningkatan kompetensi pedagogik para guru model atau mahasiswa Bahasa Inggris yang terlibat dalam Lesson Study. Pelaksanaan Wawancara dilaksanakan setelah peneliti dan guru model menyepakati waktu yang disesuai di luar jam kelas di Sekolah pelaksanaan Lesson Study masing-masing. Lembar wawancara terdiri dari 15 pertanyaan berkaitan dengan pelaksanaan Lesson Study pada pelaksanaan Praktik Pengalaman Lapangan (PPL) di Sekolah Menengah Pertama (SMP), semua pertanyaan diberikan kepada 5 mahasiswa Pendiddikan Bahasa Inggris yan terlibat pada program Praktik Pengalaman Lapangan di SMP sebagai guru model atau responden dalam penelitian ini.

Berikut hasil analisis dari pelaksnaan wawancara tersebut. Berkaitan dengan pertanyaan pertama tentang apakah Lesson Study dapat membantu perencanaan pembelajaran Anda. Guru model menyatakan bahwa pelaksanaan atau mengikuti pelaksanaan Lesson Study dapata membantu proses perencanaan pembelajaran mereka, dimulai dari perencanaan, persiapan breifing open kelas, pelaksanaan $D O$ sampai dengan pelaksanaan refleksi (SEE). Selain saran dari guru model, dosen pendamping juga memberikan masukan yang bermanfaat atas RPP yang dibuat sebelumnya, saran dan masukan sangat bermanfaat pada setiap komponen perangkat pembelajaran yang disajikan di dalam kelas. Sebaimana yang disampaika oleh guru model sebagai berikut.

Tahapan-tahapan Lesson Study sangat membantu kami dalam mempersiapkan perangkat pembelajaran yang akan diajarkan di dalam kelas, dan melalui sesi PLAN kami diberikan masukan dan saran perbaikan perangkat pembelajara. Pada sesi DO kami diamati oleh guru model lain dengan fokus pada pembelajaran, selain itu saran dosen pendamping cukup penting dalam mengarahkan para guru model.pada sesi SEE nuansa sharing pendapat menjadi menu utama dalam diskusi sehingga menunjukkan arah perbaikan kompetensi pedagogik kami sebagai mahasiswa yang praktik di Sekolah.( RS, Guru Model)

Selanjutnya pada pertanyaan kedua dalama wawancara tersebut adalah apakah tahapan Lesson Study membantu pengajaran anda. Para guru model merasakan memiliki banyak manfaat setelah mengikuti Lesson Study, hal ini disebabkan saran perbaikan perangkat pembelajaran yang digunakan mendapat banyak masukan dari teman guru model lainnya dan dosen pendamping, selain itu tahapan demi tahapan Lesson Study menambah pengetahuan pedagogik mereka dalam menyusun komponen 
RPP dan perangkat pembelajaran lainnya: memilah indikator, media belajar, metode dan pendekatan yang sesuai dan harus digunakan dalam pembelajaran,sehingga proses pembelajaran pun tidak berjalan asal-asalan.

"Tahapan Lesson Study sangat membantu saya saat pengajaran saya berlangsung dikarnakan dalam Lesson Study tahapannya sangat baik sekali. Tahapan pertama adalah merencanakan (PLAN), sebelum kita mengajar kita akan merencanakan perencanaan pembelajaran kita yang baik dan benar agar siswa dapat memahami tujuan pembelajaran kita. Tahapan kedua adalah melaksanakan (DO), disini kita akan melaksanakan apa yang telah kita rencanakan setelah itu tahapan terakhir adalah melihat (SEE) kita akan melihat guru model lain yang akan mengajar sesuai dengan perencanaan pembelajarannya atau RPP." (Herlina, Guru Model SMP Negeri 7 Tarakan).

Pada pertanyaan ketiga dari sesi wawancara, peneliti menanyakan manfaat yang diperoleh dari tahapan Breifing pada Lesson Study. Para guru model memperoleh manfaat untuk dapat lebih mempersiapakan mental dalam mempersiapakan perangkat pembelajaraa yang akan dilaksanakan di kelas, juga mempersipkan motivasi dan upaya-upaya dalam mendorong siswa dalam mengikuti proses pembelajaran di kelas, serta siap menghadapi tahapan DO dan semua masukan dan saran dari guru model lain dan dosen pendamping.

Selanjutnya, peneliti menanyakan perihal manfaat dari pelaksanaan Perencanaan (PLAN) pada Lesson Study kaitannya dengan persiapan pembelajaran guru model. Para guru model menyadari dan sudah memahami dengan baik tahapan demi tahapan, pada PLAN mereka menyadari bahwa tahapan ini akan banyak masukan dan saran dari teman-teman guru model dan dosen pendamping terkait perangkat pembelajaran dan terutama pada komponen RPP: identitas pembelajaran, alokasi waktu, kompetensi inti, kompetensi dasar, indikator pembelajaran, tujuan pembelajaran, materi, evaluasi serta sumber dan media pembelajaran yang akan disajikan di kelas. Sejalan dengan data temuan, Mulyana (2007) dan Sudrajat (2008) menguraikan secara ringkas bahwa dari empat tahapan penyelenggaraan Lesson Study yaitu, pada tahapan perencanaan (Plan) para guru yang tergabung dalam Lesson Study saling berkolaborasi untuk menyusun RPP yang akan disampaikan di depan kelas.

Pada pertanyaan berikutnya apakah saran para pengamat terkait siswa Anda di kelas dapat meningkatkan kemampuan anda dalam merumuskan strategi berkomunikasi efektif, empatik, dan santun secara lisan atau bentuk lain. Guru model menemukan saran dari guru model lain atau dosen pendamping dalam hal interaksi guru dan siswa, siswa dan materi pembelajaran, di mana guru selalu berkomunikasi dan selalu menanyakan apakah siswa sudah dapat memahami atau mengalami kesulitan dalam mengikuti pembelajaran, selain itu penggunaan bahasa yang santun dan empatik dapat mendorong siswa bersemangat dalam menyelesaikan tugas yang dibebankan kepada mereka, dengan pergerakan guru berpindahpindah ke kelompok satu ke kelompok lainnya. Hal ini dapat melahirkan komunikasi yang efektif dan strategi yang baik dalam membangkitkan selera belajar siswa.

Sementara itu, menurut Lesson Study Project (2007) yang dikutip Akhmad Sudrajat (2008: 54) beberapa manfaat lain yang bisa diambil dari Lesson Study, diantaranya; 1) guru dapat memperoleh umpan balik dari anggota/komunitas lainnya, 2) guru dapat mempublikasikan dan mendiseminasikan hasil akhir dari Lesson Study. Guru model mendapatkan masukan evaluasi pembelajaran yang didasari dari indikator pembelajaran dan jumlah yang mewakili setiap indikator di jumlah soal, selain itu alat penilaian yang berbentuk pelaksanaan unjuk kerja juga banyak mendapatkan masukan terhadap komponenkomponen penilaian language productive dan receptive.

\section{Pembahasan}

siklus pertama guru model pertama

Dalam siklus pertama indikator pembelajar harus jelas pada kata kerja yang peserta didik lakukan secara teratur sistematis dan beraturan.

Tujuan pembelajaran sebaiknya merujuka pada indikator pembelajaran, sehingga tujuan akhir dapat tercapai dan terukur melalui evaluasi pembelajarn yang diberikan pada akhir pelajaran.

Sumber belajar harus tertulis dengan jelas dan informatif agar observer atau guru mode lain dapat menjadikannya sebagai rujukan pembelajaran bagi mereka. 
Pada aspek penilaian dengan melibatkan siswa di depan kelas cukup baik

Siklus pertama guru model 2. Indikator pembelajaran harus jelas termaknai dan tidak boeh berlebihan pada satu kata kerja operasional yang dipergunakan, jadi cukup satu kata kerja operasional yang dapat diukur dalam pembelajaran ini, yaitu mengidentifikasi.

Tujuan pembelajaran tidak merujuk pada indikator pembelajaran dan tata bahasa Gerund dan Infinitive tidak konsisten.

Pelaksanaa Kegiatan awal dengan mereview pembelajaran lalu, berfungsi mengingatkan siswa untuk senantias belajar di rumah.

Pada kegiatan inti sintak pembelajaran akan memudahkan dan membantu guru untuk menjadikan RPP sebagai Self reminde. Sintaksintak pemebelajaran yang baik kan memudahkan guru untuk melaksanakan tahapan DO dengan baik. Kegiatan Akhir senantiasa harus diakhiri dengan pemberian assessment untuk membudayakan anak untuk selalu berusaha fokus dalam setiap pembelajaran yang disampaikan.

Kegiatan Akhir: Recall adalah diksi yanh tidak sesuai pada saat akan mengakhiri pelajaran, selain Review. Guru memberi penguatan atau reinforcement dan memberikan Moral lesson atas pelajaran tersebut.

Sumber belajar harus tertulis dengan jelas dan informatif agar observer atau guru mode lain dapat menjadikannya sebagai rujukan pembelajaran. Guru memfokuskan pada tingkat pronounciation dan konten yang ingin disampaikan dengan memperhatikan jumlah siswa. Guru model 3. Indikator pembelajaran pada RPP sebelum direvisi menunjukkan beberapa kata kerja operasional yang tidak tersusun dengan baik dan terjadi pengulangan pada kegiatan siswa.

Tujuan pembelajaran

Terdapat 2 tujuan pembelajaran yang diambil dari indikator pembelajaran yang direvisi.

Pelaksanaa Kegiatan awal dengan

mereview pembelajaran lalu, berfungsi

mengingatkan siswa untuk senantias belajar di rumah.

Pada kegiatan inti sintak pembelajaran sudah nampak dengan jelas pada interaksi pembelajaran , sedangkan kegiatan akhir juga sudah dapat dilakasanakan dengan baik oleh guru melalui beberapa feedback dan review pembelajaran dengan baik.

Rubrik penilaian yang disampaikan terlalu banyak dengan lembaran-lembaran penilaian yang ada, hal ini dapat menyita waktu yang cukup banyak dengan jumlah siswa yang banyak juga

Guru model 4. Indikator pembelajaran harus jelas termaknai secara beraturan dari hal yang mudah sampai hal yang sulit, sehingga kognisi siswa dapat memahami dengan baik, selain itu indikator harus mengandung satu kata kerja operasional.

Tujuan pembelajaran dapat merujuk pada indikator pembelajaran, atau dapat mengakumlasi dengan menggunakan kata kerja operasional yang tidak dapat diukur(memahami, mengetahui, mengerti dll) atau dapat diukur (mempraktikan dll) Pelaksanaa Kegiatan awal , Guru sudah dapat menunjukkan K1 dan apersepsi pembelajaran. Pada kegiatan inti sintak pembelajaran akan memudahkan dan membantu guru untuk menjadikan RPP sebagai pemandu guru dalam melaksanakan proses pembelajaran di dalam kelas.

Kegiatan Akhir senantiasa harus diakhiri dengan pemberian assessment untuk membudayakan anak untuk selalu berusaha fokus dalam setiap pembelajaran yang disampaikan, Guru memberi penguatan atau reinforcement dan memberikan Moral lesson atas pelajaran tersebut serta penilaian langsung atas hasil kerja siswa. Sumber belajar harus tertulis dengan jelas dan informatif agar observer atau guru mode lain dapat menjadikannya sebagai rujukan pembelajaran.

Dengan adanya penilaian langsung, siswa akan menjadi lebih focus dan bersungguhsungguh dalam mengerjakan tugas yang diberikan.

Guru belajar 5. Indikator pembelajaran harus jelas termaknai secara beraturan dari hal yang mudah sampai hal yang sulit, sehingga kognisi siswa dapat memahami dengan baik, selain itu indikator harus mengandung satu kata kerja operasional.

Tujuan pembelajaran dapat merujuk pada indikator pembelajaran, atau dapat mengakumlasi dengan menggunakan kata kerja operasional yang tidak dapat diukur(memahami, mengetahui, mengerti dll) atau dapat diukur (mempraktikan dll) 
Pelaksanaa Kegiatan awal , Guru sudah dapat menunjukkan K1 dan apersepsi pembelajaran.

Pada kegiatan inti sintak pembelajaran akan memudahkan dan membantu guru untuk menjadikan RPP sebagai pemandu guru dalam melaksanakan proses pembelajaran di dalam kelas.

Kegiatan Akhir senantiasa harus diakhiri dengan pemberian assessment untuk membudayakan anak untuk selalu berusaha fokus dalam setiap pembelajaran yang disampaikan, Guru memberi penguatan atau reinforcement dan memberikan Moral lesson atas pelajaran tersebut serta penilaian langsung atas hasil kerja siswa.

Sumber belajar harus tertulis dengan jelas dan informatif agar observer atau guru mode lain dapat menjadikannya sebagai rujukan pembelajaran.

Dengan adanya penilaian langsung, siswa akan menjadi lebih focus dan bersungguh-sungguh dalam mengerjakan tugas yang diberikan.

peniliaan speaking performance sesuai dengan tingkatan dan fokus pada subtansi percakapan dengan menggunakan media telepon. Performance, Pronounciation, Grammar, dan Content.Pelaksanaan siklus kedua

Guru belajar 6. Sintak-sintak pembelajaran sebaiknya harus lebih detail karena RPP merupakan guideline bagi setiap guru dalam melaksanakan proses pembelajaran di dalam kelas (guru penganti jika sewaktu-waktu guru tersebut berhalangan hadir). Teknik peniliaan tertulis, lisan, non tes, performance, projek dll Scientific approach sudah otomatis pada RPP yang menggunakan K13.

Kesalahan dalam penyusunan Indikator pada RPP kedua ini adalah indikator tidak tersusun (sequence) terhadap materi yang disampaikan, dan tujuan sebaiknya dapat menggunakan kata kerja operasional memahami. Sintak-sintak pembelajaran sebaiknya harus lebih detail pada penjeasan konteks materi dan expektsi guru model terhadapa siswa.

\section{SIMPULAN DAN SARAN}

Berdasarkan hasil penelitian dan pembahasan sebelumnya, maka dapat disimpulkan sebagai berikut: 1) Lesson Study dapat meningkatkan kompetensi pedagogik mahasiswa senagai guru model pada pelaksanaan nya di Sekolah Menengah Pertama (SMP) di
Kota Tarakan, terlihat meningkatnya motivasi mengajar mahasiswa yang terlibat dalam lesson study pada Praktik Pengalaman Lapangan (PPL) dengan tahapan pelaksanaan yang dimulai dari tahapan PLAN, DO dan SEE. 2) Terdapat perbedaan dalam persiapan pengajaran pada mahasiswa di mana dengan Lesson Study dapat melahirkan interaksi guru-siswa, dan siswa dengan materi pembelajaran secara positif.

Hasil penelitian ini merekomendasikan pelaksanaan Praktik Pengalaman Lapangan dilaksanakan di Sekolah dengan pendekatan Lesson Study yang berkelanjutan dan menjadi agen pembelajaran (learning agent) adalah peran guru antara lain sebagai fasilitator, motivator, pemacu, perekayasa pembelajaran, dan pemberi inspirasi belajar bagi peserta didik (UU 2014, pasal 4). Sehingga calon guru dapat menjadikan Lesson Study sebagai budaya yang berkelanjutan bagi calon guru.

\section{DAFTAR RUJUKAN}

Bungin.B. (2001). Metodlogi Penelitian Kualitatif. Raja Grafindo Persada. Jakarta

Depdiknas. (2005). UU RI No. 14 Tahun 2005 Tentang Guru dan Dosen. Bandung: Fokusmedia.

Sugiyono. (2012). Memahami penelitian kualitatif. Bandung: ALFABETA.

Sugiono.(2010). Metode Penelotian Pendidikan: pendekatan kualitatif, kuantitatif dan $\mathrm{R}$ and D. Alfabeta. Bandung

Thornburg, D H. (1982). Development in Adolenscence. Second Edition. California: Brook Cole Publishing Co.

White, Allan,L. dan Lim. (2007). Lesson Study.: Local Global or a global strategy for teavher professional learning? Paper presented at the second International Conference science and mathematics Education, 13-16 November. Penang, Malaysia 